\title{
DISCURSOS SOBRE A VOZ DE LULA NA MÍDIA BRASILEIRA
}

\author{
Carlos Piovezani ${ }^{*}$ \\ Universidade Federal de São Carlos \\ Centro de Educação e Ciências Humanas \\ São Carlos, SP, Brasil
}

\begin{abstract}
Resumo: Desde o anúncio do câncer de laringe de Lula em outubro de 2011, vimos surgir um amplo e disperso conjunto de textos sobre os riscos que a doença representava para a voz do ex-presidente do Brasil. Fundamentados na Análise do discurso, derivada de Michel Pêcheux, nossa proposta consiste em interpretar alguns dos enunciados da mídia brasileira que trataram da voz de Lula, na tentativa de identificar as distintas posições de seus enunciadores e seus diferentes sentidos. Buscamos, ainda, empreender uma reflexão sobre certos aspectos da memória e da história brasileira conservados na voz de uma de suas personagens mais importantes, no intuito de aventar possíveis respostas às seguintes questões: por que se falou tanto de sua voz? Quais são as posições e os sentidos dessas falas sobre a voz de Lula? Qual o papel que ela desempenhou em suas falas públicas, na composição de seu carisma e em seu sucesso político?
\end{abstract}

Palavras-chave: Discurso. Voz. Mídia.

\section{INTRODUÇÃO}

"O mais proveitoso e natural exercício de nosso espírito é, a meu ver, a conversação. É-me a sua prática mais agradável do que qualquer outra. Eis por que, se me coubesse escolher, antes consentiria, penso, em perder a vista do que o ouvido e a fala" (MONTAIGNE ([1595] 1987, p. 243). Encontramos esta afirmação de Montaigne no capítulo VIII, intitulado "Da arte de conversar", do livro III de seus Ensaios.

Mutatis mutandis, quatro séculos mais tarde e do outro lado do Atlântico, numa noite de abril de 2012, em entrevista exibida pela TV Cultura, Lula também trata, mais dramática e emotivamente do que o fizera o ensaísta francês, da possibilidade de perder a voz: "Eu, eu, eu sinceramente, eu diferentemente de muita gente, eu tinha mais preocupação de perder a voz do que de morrer. Ou seja, porque eu, se eu perdesse esta voz, eu já tava morto; entende?". Sua maior preocupação com a voz do que com a morte reitera a seu modo o que tantos já haviam dito sobre os riscos que ele corria, caso se desse a perda de sua voz ou uma sua significativa alteração, motivada pelo câncer na laringe de que ele até então estava acometido. Lula parecia possuir uma boa medida da força contida em sua voz, após o anúncio da cura de sua doença.

A partir da divulgação do câncer sofrido pelo ex-presidente, cujo diagnóstico fora veiculado em outubro de 2011, surgiu uma grande e heterogênea série de textos sobre os riscos que a doença apresentava para sua voz e, por extensão, para sua atuação na vida

\footnotetext{
* Doutor em Linguística e Língua Portuguesa. Professor Adjunto III. Email: cpiovezani@uol.com.br; cpiovezani@ufscar.br.
} 
pública brasileira. Em vários domínios sociais, emergiram enunciados acerca da enfermidade do antigo sindicalista e de suas possíveis e nefastas sequelas: a doença de Lula e os riscos que ela representava para sua voz de foram tema de conversas cotidianas, de mensagens em redes sociais, de debates entre profissionais da saúde, de comentários da classe política, de notícias e artigos da mídia. Fundamentados na Análise do discurso (AD), derivada de Michel Pêcheux, nossa proposta aqui consiste em interpretar alguns desses enunciados de parte da imprensa brasileira, nos quais a voz de Lula foi tematizada, na tentativa de depreender suas distintas posições ideológicas, a partir da identificação dos discursos de que provêm esses enunciados. $\mathrm{Na}$ esteira de Pêcheux, o conceito de formação discursiva é aqui compreendido como a instância que determina o que pode e deve ser dito e que produz os efeitos de sentidos entre os sujeitos das diversas condições de produção (PÊCHEUX, 1997b, p. 160).

Além disso, buscaremos ainda estabelecer uma reflexão sobre certos aspectos da memória nacional conservados na voz e nas falas de uma das figuras mais importantes da história do Brasil. Ou seja, diante dessa efervescência de textos sobre a voz do exmetalúrgico que se tornou presidente da República, ocorreram-nos as seguintes questões: quando a voz torna-se objeto de comentários e discussões? Quais são as posições dos enunciadores e os sentidos dos enunciados midiáticos sobre a voz de Lula? Qual o papel que ela desempenhou em sua retórica popular, na composição de seu carisma e em seu sucesso político? Sem termos a pretensão de responder exaustivamente a essas perguntas, gostaríamos ao menos de esboçar aqui uma breve interpretação a seu respeito.

Para tanto, organizamos nosso texto do seguinte modo, visando à formulação de respostas àquelas questões: inicial e brevemente, discorreremos sobre alguns postulados e noções fundamentais da $\mathrm{AD}$, que serão retomados na análise que realizaremos; em seguida, formularemos uma hipótese acerca das circunstâncias em que mais frequentemente falamos da voz; após a apresentação dessa hipótese, procederemos à análise de alguns enunciados de parte da imprensa nacional sobre a voz de Lula - mais precisamente serão analisados textos do jornal Folha de São Paulo, das revistas Época e Serrote; e, finalmente, na última parte de nosso trabalho, além de apresentarmos uma síntese dos resultados obtidos no exercício analítico que empreendemos anteriormente, esboçamos uma reflexão especulativa acerca da função desempenhada por sua voz e por seu estilo de fala pública na construção de sua popularidade e na "reforma gradual" e no "pacto conservador" (cf. SINGER, 2012) que ele produziu na história do Brasil.

\section{DISCURSO E A PRODUÇÃO DOS SENTIDOS}

Gestado no interior do Materialismo histórico, a cujos princípios articularam-se saberes da Linguística e da Psicanálise, o conceito de discurso em Pêcheux não corresponde ao caráter universal da língua para todos os membros de uma comunidade linguística nem tampouco à condição individual da fala para cada um deles; para Pêcheux, o discurso caracteriza-se, antes, pela normatividade de uma prática, que é determinada pelas lutas de classe. Assim, entre a universalidade da língua e a singularidade individual da fala estaria situado um "nível intermediário", "o nível da 
particularidade, que define "contratos' linguísticos de tal ou tal região do sistema" (PÊCHEUX, 1997a, p. 74). Envolvendo relações de força e de sentido, uma vez que se inscreve nos conflitos e contradições ideológicas e, ao mesmo tempo, nas remissões a outros dizeres, o discurso é concebido por Pêcheux não como transmissão de informação, mas como "efeito de sentidos" entre interlocutores (PÊCHEUX, 1997a, p. $82)$.

Ora, as relações de força materializam-se nas relações entre os dizeres de uma sociedade, por meio das ideologias. Estas também são compreendidas em sua condição de "nível intermediário", pois cada uma delas pode ser definida como

\begin{abstract}
um elemento suscetível de intervir, tal como uma força confrontada a outras, na conjuntura ideológica característica de uma formação social, em um dado momento; cada formação ideológica constitui assim um conjunto complexo que comporta atitudes e representações que não são nem 'individuais' nem 'universais', mas que se referem mais ou menos diretamente a 'posições de classe' em conflito umas com as outras" (HAROCHE; HENRY; PÊCHEUX, 1971, p. 102).
\end{abstract}

O discurso é entendido como uma forma privilegiada de materialização das ideologias, tendo em vista o fato de que as formações ideológicas compreendem necessariamente uma ou várias formações discursivas, no interior das quais e em cujas relações se determina "o que pode e deve ser dito [...], a partir de uma dada posição numa determinada conjuntura" (HAROCHE et. al., 1971, p. 102).

Desse modo, ao materializar as ideologias, que, por seu turno, já são materializações dos conflitos de classe, o discurso determina o dizer e produz os sentidos. Distintamente de outros campos de conhecimento, na AD os sentidos das unidades linguísticas não estão nas coisas empíricas do mundo das quais elas são signos, nem no tempo passado daquele que teria sido seu motivado e natural advento. Em alguma medida e a despeito de suas diferenças, certas etimologias e algumas filologias, por exemplo, compartilham a ideia de que se deve buscar no passado o verdadeiro sentido das palavras e das frases, visto que a passagem do tempo abafaria o murmúrio significativo das coisas do mundo, degeneraria a língua e deturparia suas significações. Tampouco é das convenções humanas e das intenções subjetivas que derivam os sentidos do discurso, cuja constituição teria sido estabelecida num presente mítico, em que ocorre um contrato social, mediante o qual se instauram para todos os mesmos significados. Não se trata, portanto, nem de algo pré-fixado e imutável nem de variações individuais que responderiam às intenções do falante: "O sentido, para a AD, não está fixado a priori como essência das palavras, em tampouco pode ser qualquer um: há a determinação histórica." (ORLANDI, 1998, p. 27). Por seu turno, Haroche, Henry e Pêcheux sustentam e destacam essa concepção discursiva dos sentidos na seguinte passagem

o ponto essencial aqui é que não se trata somente da natureza das palavras, mas também e sobretudo das construções nas quais essas palavras se combinam, na medida em que essas construções determinam a significação que as palavras terão; conforme indicamos, as palavras mudam de sentido segundo as posições sustentadas por aqueles que as empregam. Podemos precisa-lo agora: as palavras 'mudam de sentido' ao passar de uma formação discursiva para outra. (1971, p. 102-103; grifos dos autores). 
Num outro texto, Pêcheux falará do "caráter material do sentido" na abordagem discursiva oposto à "transparência da linguagem", que faz crer nas evidências da significação. Retomando a reflexão anterior, o autor afirma que

\begin{abstract}
o sentido de uma palavra, de uma expressão, de uma proposição, etc., não existe 'em si mesmo' (isto é, em sua relação transparente com a literalidade do significante), mas, ao contrário, é determinado pelas posições ideológicas que estão em jogo no processo sóciohistórico no qual as palavras, expressões e proposições são produzidas (isto é, reproduzidas). (...) recebem seu sentido da formação discursiva na qual são produzidas." (PÊCHEUX, 1997b, p. 160-1).
\end{abstract}

Em suma, a Análise do discurso nos ensina que diante dos textos e enunciados frequentemente muito semelhantes entre si é preciso identificar a posição da qual cada um deles provém. Há nos textos que trataram da possibilidade da perda da voz de Lula ou de uma sua sensível alteração afirmações, em princípio, bastante similares, tais como os votos de restabelecimento de saúde e as declarações de que a voz é uma das marcas e ainda uma das forças do ex-presidente. Mediante uma análise discursiva que identifica as posições a partir das quais esses enunciados foram produzidos, tencionamos demonstrar, conforme dissemos, que eles constroem efeitos distintos, quando não, opostos. Antes, porém, de passarmos à análise de alguns enunciados da mídia brasileira sobre a enfermidade de Lula e suas possíveis sequelas, faremos algumas considerações sobre o surgimento de discursos sobre a voz, com base na retomada de passagens de um ensaio intitulado "A voz humana", de Anne Karpf (2008), no intuito de aventarmos uma hipótese a respeito da emergência desses discursos. Aspiramos a formular uma resposta provisória e especulativa para a questão que dá título ao próximo item de nosso texto.

\title{
3 QUANDO SE FALA SOBRE A VOZ?
}

Em depoimentos de populares, sob a forma de respostas a uma questão sobre a facilidade e/ou dificuldade para falar sobre a voz, colhidos em "entrevistas individuais semiabertas" (GOBBI, 2004), observamos a possibilidade de reiterar nossa hipótese (PIOVEZANI, 2011), segundo a qual os discursos sobre a e em defesa da voz surgem mais frequente e intensamente quando ela se encontra real ou imaginariamente ameaçada. Se, por um lado, os elementos vocais podem agregar-se às paráfrases e aos "efeitos metafóricos" (PÊCHEUX, 1990, p. 96), que, constituídos no interior de uma formação discursiva, produzem os efeitos de sentido do discurso, conforme também sustentamos em Piovezani (2011, p. 166), ou podem incidir decisivamente na produção das subjetividades, tal como já fora demonstrado por Souza $(2012 ; 2014)^{1}$, por outro, nesta nossa reflexão e nas análises que aqui a acompanham, interessa-nos abordar a voz como tema de discurso e não em suas propriedades prosódicas.

\footnotetext{
${ }^{1}$ As relações entre discurso, voz e produção de subjetividades têm sido objeto dos trabalhos de Pedro de Souza (UFSC). O objetivo geral desses seus estudos, que já compõem uma obra considerável e da qual destacamos a título de ilustração somente dois textos (SOUZA, 2012 e 2014), consiste em investigar os discursos sobre a voz que canta em enunciados produzidos pela voz que fala, nos quais se materializam as memórias do momento em que o sujeito tornou-se cantor(a). Souza tem ressaltado que se trata aí de um ritual enunciativo particularmente importante na constituição desse sujeito.
} 
A despeito da onipresença da atividade epilinguística na fala humana, ou seja, dessa faculdade que faz com que constantemente falemos de nossa fala, a voz parece ser amiúde silenciada no dizer sobre o dizer, caso não se encontre de algum modo em perigo e não concentre em si algum poder, que sejam mais ou menos extraordinários. Eis abaixo alguns desses depoimentos:

A gente fala, não presta atenção na, na voz. A não ser que você esteja gripada, alguma coisa. Mas se você vai falando no dia a dia, você não percebe o tom da voz [...].

Falar sobre a voz não foi muito fácil, porque a gente, eu nunca tinha percebido, nunca tinha alertado sobre a voz. [...] a voz é um negócio assim importantíssimo, mas eu nunca parei para falar da voz.

Não, não é difícil. Mas é porque a gente nunca teve a oportunidade de ninguém tá perguntando pra gente pra falar sobre voz, né? (apud GOBBI, 2004, p. 81-83)

Em seu ensaio sobre a voz humana, Karpf (2008, p. 26-27) também se refere a esse fenômeno:

A cultura ocidental durante muito tempo foi praticamente impermeável à voz. [...] Nos últimos vinte anos, vimos nascer, contudo, um extraordinário interesse pela linguagem seus modos de aquisição, as capacidades e as regras que regem seu uso. Esse fascínio pelo que nós dizemos e por nossas maneiras de dizer estranhamente continuou, no entanto, a marginalizar a voz. A maior parte dos estudos linguísticos sobre a conversação deixa de lado o veículo que a torna possível. [...] A linguagem é considerada como portadora essencial do sentido, como se a voz fosse apenas o veículo das palavras. Tudo se passa como se a voz somente atraísse a atenção em caso de problema.

Outra questão constante nas entrevistas de Gobbi (2004, p. 43) era "Você já se imaginou sem voz?", da qual derivaram respostas como as seguintes, por exemplo:

Ia ser impossível, eu acho, pra mim, agora. (...) Deve ser angustiante. Porque você vai querer se expressar, falar alguma coisa, fica travado; acho que a primeira coisa vai tentar soltar um berro, colocar a mão na garganta [...]!

E quando você fica rouco e não pode falar, eu acho que angustia muito. Então a voz pra mim é assim, importante, tanto quanto o sangue... é a voz! O sangue alimenta e a voz retrata tudo que a gente, que a gente é, que a gente quer, né?!

Nossa! Acho que eu ia, eu ia ficar doida; porque falar é muito bom. Eu gosto de falar. Eu acho que se eu ficasse, se eu fosse uma pessoa sem voz, muda, eu não sei o que eu seria... (apud GOBBI, 2004, p. 44-45)

No domínio cotidiano e em outros campos, parece, portanto, que se fala da voz predominantemente quando ela está sob ameaça. E os perigos que podem afetá-la incidem nos processos de produção das subjetividades, uma vez que, conforme dizeres antiquíssimos cujos ecos ainda chegam fortes aos nossos ouvidos, a voz é lugar 
privilegiado para a construção e/ou expressão das identidades sociais e individuais (PARRET, 2002). Com maior ou menor frequência, ouvimos enunciados similares aos seguintes: "A voz é única em cada indivíduo e revela privilegiadamente nossas paixões, emoções e sentimentos." A força e a conservação dessas falas sobre a voz podem ser manifestamente observadas em sua ocorrência nos tratados de retórica antiga, principalmente em Cícero e Quintiliano, e em sua frequente reiteração em nossos dias ${ }^{2}$. Há ainda muitos outros dizeres sobre a voz, tais como os formulados ou retomados por Karpf (2008):

\begin{abstract}
As inflexões da voz são frequentemente mais eloquentes que as próprias palavras. [...] A voz se encontra no coração da natureza humana, pois ela pertence simultaneamente ao corpo e ao espírito. [...] A voz permite detectar o tamanho, o peso, o porte físico, o sexo, a idade e a profissão e, frequentemente, até as orientações sexuais da pessoa que fala; e permite ainda, eventualmente, detectar a classe social, a origem étnica e por vezes o nível de educação (KARPF, 2008, p. 13-23).
\end{abstract}

Um paradoxo parece então envolver a voz: ela é, por um lado, fundamental e onipresente nas relações dos sujeitos em sociedade e, por outro, praticamente ignorada, quando ao abrigo de perigos que a ameacem, numa mistura entre vocofilia e, se não propriamente uma vocofobia, ao menos certo desprezo pela voz... A primeira estaria representada, por exemplo, além das propriedades acima referidas, pela condição da escuta de ser um dos primeiros sentidos que se forma no feto já a partir da oitava semana da gestação; pelo fato de a audição ser o último dos sentidos a descansar antes de dormirmos e o primeiro a se despertar quando acordamos (KARPF, 2008, p. 50). Ademais, para satisfazer nossas necessidades simbólicas e históricas, toleramos com muito boa vontade certo desconforto respiratório, sacrificamos em alguma medida o mecanismo de respiração, indispensável à vida, para fornecermos a energia exigida pela produção da fala, e fizemos de certas regiões de nosso cérebro zonas particularmente sensíveis à voz humana, que são por ela selecionadas e ativadas (KARPF, 2008, p. 5455).

Com efeito, em distintos campos de saber, a voz foi objeto de interesse e dela foram ressaltas nobres funções e virtudes. Tal fato pode ser observado emblematicamente nas identidades e diferenças apontadas por Salazar (2008) entre o que os retores antigos e modernos e os anatomistas italianos do século XVII disseram sobre a voz humana e o que, por sua vez, Darwin afirmava sobre ela em seus escritos acerca da teoria da evolução. A despeito de suas diferenças, a retórica e a ciência natural sublinham que a voz é um elemento decisivo da fala sedutora que serve para

\footnotetext{
agir, para melhor agir, para melhor agir sobre o outro - quer seja para o bem da espécie (para Darwin) quer seja para o bem da cidade (para a retórica). Voice e vox agem de maneira equivalente, tanto em relação às suas causas (as paixões motrizes) quanto em relação aos seus fins (poder mais bem agir) e ainda em relação à sua ancoragem num sistema mais amplo (a espécie, em Darwin; e a cidade, na retórica. (SALAZAR, 2008, p. 45).
}

\footnotetext{
${ }^{2}$ Vide, por exemplo, a entrevista concedida pela fonoaudióloga Maria Aparecida Coelho ao médico Dráuzio Varela, que pode ser lida no seguinte link: $<$ http://drauziovarella.com.br/envelhecimento/voz-3/>
} 
Em contrapartida, a voz é não raras vezes concebida como mero meio material em cuja substância os sentidos são veiculados. Sua condição de substância material não impede que ela seja concebida em sua natureza mais ou menos evanescente e em sua qualidade relativamente fugaz, cujo funcionamento físico se coaduna muitíssimo bem com o imaginário de que o que realmente importa são as ideias, como se essas fossem independentes dos conflitos da história inscritos materialmente nos objetos simbólicos, na "forma-material", de que fala Orlandi (1998, p. 31).

Uma vez que a voz de Lula encontrava-se ameaçada por sua doença, falou-se muito a seu respeito. A dispersão de textos que contemplaram essa temática pode ser mais bem compreendida, à medida que identificamos a pertença de seus enunciados a certos discursos e a de seus enunciadores a determinadas posições ideológicas e a dadas formações discursivas. É nessa direção que logo abaixo se projeta o exercício de análise de alguns enunciados da mídia brasileira que foram produzidos por ocasião do anúncio do câncer de laringe de Lula e que tematizaram sua doença e sua voz.

\section{OS SENTIDOS DA VOZ DE LULA NA MÍDIA BRASILEIRA}

Se as relações de força e de sentido podem frequentar os usos da voz na sociedade em geral, com mais razão, tendem a frequentá-los em alguns domínios discursivos, tal como o campo do discurso político, e tanto mais quando se trata da principal figura da política brasileira contemporânea. Conforme dissemos, a divulgação do câncer de laringe de Lula produziu um amplo e disperso conjunto de textos acerca dos riscos que corria sua voz: conversas do cotidiano, posts e twits em redes sociais, debates entre profissionais da saúde da voz, comentários de políticos, notícias, crônicas e reportagens da mídia etc. Tal conjunto comporta um variado leque de dizeres que vão de eventuais imprecações, passando por declarações mais ou menos referenciais, até os predominantes votos de pronto restabelecimento. Ao tomarmos como objeto de interpretação alguns enunciados da mídia impressa brasileira, nos quais se expressam esses votos e se reitera a ideia de que o ex-presidente possui na voz uma de suas forças - tais como "Uma das forças de Lula é a voz" / "É uma boa notícia para todos que Lula tenha recuperado a voz e se sinta curado", formulados respectivamente em textos de edições abaixo citadas do jornal Folha de S.Paulo e da revista Época -, interessa-nos demonstrar que eles não provêm das mesmas posições e não produzem definitivamente os mesmos efeitos de sentido.

A título de exemplo, tomemos o caso da coluna de Eliane Cantanhêde, publicada na edição de 30 de outubro de 2011 do jornal Folha de S. Paulo, logo no dia seguinte à difusão da notícia da doença de Lula. Eis precisamente algumas das palavras da colunista da Folha:

\footnotetext{
Uma das forças de Lula é a voz, a imensa, a impressionante capacidade de comunicação desse político inato que saiu de um casebre no interior do Nordeste e cativou o mundo. A voracidade política e as eleições municipais de 2012 serão decisivas para salvá-lo. Lula virou o que virou pela inteligência, o carisma e a voz. Ela não irá lhe faltar.
} 
Um breve exercício analítico do enunciado "Uma das forças de Lula é a voz", relacionando-o aos demais dessa sequência discursiva, às suas condições de produção e à posição de seu enunciador atesta que eles são produto de um discurso no qual se afirma a aptidão comunicativa de Lula, que, por sua vez, parece relacionar-se com jáditos sobre a suposta prática dos políticos de falar muito (bem) e de nada de fato fazer para transformação da sociedade, e com seu gosto pelo poder, no pré-construído "A voracidade política", que produz na nominalização definida o efeito de que a avidez de Lula pelo poder seria uma evidência incontestável. Além da voz, as outras "forças de Lula" são a "inteligência" e o "carisma": a primeira é ali interpretada como senso de circunstância ou "esperteza" e a segunda, como ascendência que se exerce sobre outrem, mediante as imagens que o "astuto" político faz de si em suas práticas. Há ainda a produção de um efeito de empatia, sob a forma de algo que é concomitantemente um voto de restabelecimento e uma fala peremptória e profética, que em tese se quer performativa, no último enunciado da sequência, passíveis de serem observados particularmente na expressão taxativa da negação e no tempo verbal, no futuro do presente.

Porque os sentidos em Análise do discurso derivam dos processos discursivos ${ }^{3}$ que se desenvolvem no interior das formações discursivas, podemos dizer que aqueles que são ali produzidos alinham-se bastante bem àqueles produzidos em outros textos do mesmo jornal, porque provêm de uma mesma FD: Lula é espontâneo e calculista. Depois de já ter sido anunciada a cura de seu câncer, o editorial da Folha do dia 31 de março de 2012 diz o seguinte, ao comentar a entrevista concedida às repórteres Cláudia Collucci e Mônica Bergamo pelo ex-presidente e exibida, como dissemos, no dia 01 de abril daquele ano:

\begin{abstract}
Lula não é dos que optam pela sensaboria e pelo convencionalismo. Sua decantada capacidade de comunicar-se talvez tenha, no fundo, uma chave bastante simples para ser entendida. Quanto mais idiossincrático, individualizado e inconfundível o político, mais amplo, provavelmente, é o alcance de sua mensagem ao eleitorado. [...] Espontaneidade, de resto, nunca foi sinônimo de ausência de cálculo. [...] Político dos pés à cabeça, Lula é messiânico, demagógico, inconveniente, humano, simpático, calculista, esquivo, mas sobretudo real; Lula raras vezes pecou por esse aspecto.
\end{abstract}

A voz como uma das forças do ex-presidente equivale uma vez mais nessa posição à sua "decantada capacidade de comunicar-se", que por seu turno remete à ideia de tratar-se de um "político dos pés à cabeça", cujas características são: "messiânico, demagógico, inconveniente, humano, simpático, calculista, esquivo, mas sobretudo

\footnotetext{
${ }^{3}$ Em várias passagens de seus textos, Michel Pêcheux sustenta que "uma palavra, uma expressão ou uma proposição não tem um sentido que lhe seria 'próprio', vinculado à sua literalidade. Ao contrário, seu sentido se constitui em cada formação discursiva, nas relações que tais palavras, expressões ou proposições mantêm com outras palavras, expressões e proposições da mesma formação discursiva. De modo correlato, se se admite que as mesmas palavras, expressões e proposições mudam de sentido ao passar de uma formação discursiva a uma outra, é necessário também admitir que palavras, expressões e proposições literalmente diferentes podem, no interior de uma formação discursiva dada, 'ter o mesmo sentido' [...] A partir de então, a expressão processo discursivo passará a designar o sistema de relações de substituição, paráfrases, sinonímias, etc., que funcionam entre elementos linguísticos - 'significantes' em uma formação discursiva dada. (1997b, p. 160)
} 
real". A polissemia dos adjetivos dotados em princípio de valor eufórico ("humano", "simpático" e "real") é ressignificada nas combinações e substituições com as predominantes qualificações disfóricas e torna possível uma sua interpretação como falível, contraditório e dissimulado. Assim, a importância de sua voz está relacionada à sua habilidade comunicativa, que está a serviço de sua "voracidade política", cujo exercício prevê cálculo, demagogia e dissimulação.

Além de "Lula e as ironias da vida", de Eliane Cantanhêde, e do editorial da Folha, muitos outros textos da mídia que tematizaram os perigos da (e sofridos pela) voz de Lula: dois deles, aliás, que gozaram de considerável circulação, intitularam-se "A voz de Lula", um de Tales Ab'Saber, publicado em março de 2012 na décima edição da Revista Serrote, e outro de Ruth de Aquino, publicado na Revista Época nos mesmos mês e ano. Neste último, encontram-se enunciados como os seguintes:

\begin{abstract}
O presidente que cometeu mais gafes na história do Brasil conseguia quase sempre roubar a cena ao abrir a boca. [...] Sua voz rouca, com erros de português, metáforas de futebol e piados do povão, era o elo com a massa, na versão sindicalista exaltado ou do lulinha paz e amor. O Brasil teve outros oradores inflamados [...] [que] se expressavam com vigor também na escrita. Lula não. Exerce uma liderança oral. A maioria da população brasileira não domina a palavra escrita. [...] Num país assim, a voz é hipervalorizada como capital simbólico. Lula sempre falou demais. É uma boa notícia para todos que Lula tenha recuperado a voz e se sinta curado. Principalmente para Fernando Haddad, mais mudo sadio que Lula doente.
\end{abstract}

Observamos que não é exatamente o contentamento pela recuperação de Lula que está ali em relevo. Além disso, a capacidade comunicativa do ex-presidente é novamente realçada, mas, ao mesmo tempo, questionada, uma vez que se, por um lado, "conseguia quase sempre roubar a cena ao abrir a boca", se estabelecia um "elo com a massa" e se exercia uma liderança, por outro, tais elo e liderança davam-se somente na modalidade oral, supostamente cometendo gafes como nenhum outro presidente jamais o fizera, "com erros de português, metáforas de futebol e piadas do povão" e sempre falando demais. Os dois estilos do orador, "sindicalista exaltado" e "lulinha paz e amor", equivalem nas paráfrases do discurso que ali se materializa às "duas caras" do sujeito, cujo público, que o legitima com seu apoio, é também deslegitimado e descreditado: a "massa", a "maioria da população brasileira", que lhe dera os $80 \%$ de popularidade, fizera-o, porque pretensamente não domina a escrita e deixa-se ludibriar pela manipulação retórica e vocal de Lula.

De modo bastante distinto da posição predominante na mídia de grande circulação no Brasil, conforme se pode constatar pelos excertos acima reproduzidos e pela análise que deles fizemos, Ab'Saber (2012) afirma que na voz de Lula deu-se, talvez como jamais tenha ocorrido com nenhum outro político brasileiro, em várias ocasiões o encontro entre a voz do grande homem e a voz do povo (e, por isso, talvez também a de Deus), que ele representava. Seguem alguns excertos de seu texto:

\footnotetext{
E é estranha a possibilidade brusca, iminente, suspensa, da perda dessa voz que se tornou tão familiar quanto o literalmente familiar para nós, essa voz que nos constituiu muito mais do que somos capazes de dar conta no plano da mera consciência. Perdê-la, de qualquer modo, seria a morte de um tempo antes de seu próprio fim [...]. (AB'SABER, 2012, p. 656)
} 
Lula tem voz de trovão do popular que rompeu o pacto conservador do homem cordial brasileiro. [...] é o popular moderno e finalmente liberto que rompeu o gesto de ser calado pelo intelectual e pela autoridade. (AB'SABER, 2012, p. 66)

\begin{abstract}
Para quebrar aquele cala-boca real do jogo da conciliação cordial brasileira [...] com sua tradicional concentração de poder, e seu rebaixamento do popular a espectador e a matéria neutra da história, que não deveria ter voz nem mesmo para as próprias dores, era necessário um corpo muito forte, de torneiro mecânico, e uma voz muito especial, também ela forte, consciente da própria potência, que explodisse tais laços consentidos de submissão que se perdiam nas noites dos tempos mais profundos da má conciliação brasileira. (AB'SABER, 2012, p. 66-7)
\end{abstract}

\begin{abstract}
Além disso, há pedras, ou máquinas poderosas, no fundo daquela voz. [...] Essa é a voz popular que vibra, no interior do segredo de seu timbre atritoso, a experiência da vida encantada pelo horror e pela alegria, da pobreza brasileira. E mais alguma cachaça e algum cigarro. E Lula claramente tem algo dessa voz, no seu trovão gutural - e, como todos sabem desde crianças, a voz do trovão é sempre a voz de Deus - do político. (AB'SABER, 2012, p. 67)
\end{abstract}

\begin{abstract}
Aquela voz queria simplesmente capturar, em seus limites, a força histórica sempre barrada do desejo de transformação de um país que se formou e que soube se modernizar conservador. Por aquela garganta passaram as forças de milhões de homens, dos companheiros e das companheiras, e o desejo coletivo de todo um povo de produzir uma diferença histórica, em uma história que aprendeu a progredir sem transformação. Aquela voz portava a energia social coletiva que era imensamente maior que cada um de nós que a sustentava e a sonhava em um comício na praça da Sé. (AB’SABER, 2012, p. 68)
\end{abstract}

De modo aparentemente semelhante, mas efetivamente diferente do que ocorre nos textos da Folha de São Paulo e da Época, Ab'Saber fala da possibilidade de perda da voz de Lula e da força que ela concentra: essa perda significaria "a morte de um tempo, antes de seu próprio fim", tendo em vista a familiaridade e a onipresença da voz de Lula para todos os brasileiros, sejam eles seus partidários irrestritos, seus simpatizantes moderados ou seus adversários resolutos. A voz de Lula é, pois, uma das marcas de nossa época. Já sua força reside em sua energia de "trovão" capaz de romper "o pacto conservador do homem cordial brasileiro" e "o gesto de ser calado pelo intelectual e pela autoridade", de "quebrar aquele cala-boca real do jogo da conciliação cordial brasileira (...) com sua tradicional concentração de poder" e de explodir os "laços consentidos de submissão que se perdiam nas noites dos tempos mais profundos da má conciliação brasileira". Por meio da "potência" e de sua "inteligência" pela voz, marcada apropriadamente com certos traços da qualidade vocal (seu timbre é "gutural", "áspero", "belamente grave" e "atritoso"), Lula deu voz aos trabalhadores pobres brasileiros que não podiam expressar suas eventuais alegrias e nem sequer suas constantes dores e sofrimentos. Com sua "inteligência retórica concreta e popular", materializada numa "voz energizada", o sindicalista dos anos 70 enfrentou a ditadura militar e fez "exigências urgentes ao país".

O reconhecimento da força e do papel histórico desempenhado pela voz de Lula não impede que $\mathrm{Ab}$ 'Saber nela identifique as contradições da história e da sociedade brasileiras, sintetizadas e representadas na identidade e nas transformações dessa voz. É o que podemos observar nas duas seguintes passagens de seu ensaio: 
De fato, aconteceu também uma verdadeira desmobilização das exigências do discurso e da voz do político, que só era séria agora, a partir da chegada ao governo em 2003, para garantir que tudo ia às mil maravilhas em seu país da ascensão de massas ao primeiro círculo do consumo, ou para demandar tolerância e impunidade dos privilegiados para os descaminhos de seu grupo e de seus aliados no poder, quando não até para simular a própria velha voz, fazer o teatro, um teatrinho de rua, de um confronto de classes retórico para garantir ao seu povo brasileiro a identificação com o líder combativo que dava mesmo a garantia, pessoal, de que aquele povo finalmente podia se sentir incluído, no país da pior concentração de renda do mundo, que finalmente pagava, por meio da voz autopropagandística de Lula, a sua secular dívida social. Todos esses movimentos de transformação política e da voz de Lula corresponderam sintomaticamente à ausência de vozes fortes, no sentido do artista particular, uma personalidade estética da voz, ou de música forte, em uma cultura que se resolvia, por fim, apenas como cultura de consumo. (AB'SABER, 2012, p. 69)

[...] no processo de integração social inexorável [...], a voz de Lula virou por fim cimento ideológico condescendente consigo mesmo, e com tudo o que existe, a voz de um povo orientado em massa para a vida de mercado. (AB'SABER, 2012, p. 71)

A "incomensurável energia" da voz, que fala(va) em nome das urgências das classes pobres do Brasil, conhece, "a partir de sua chegada ao governo em 2003", "uma verdadeira desmobilização" e cumpre a função de anunciar que "tudo ia às mil maravilhas em seu país da ascensão de massas ao primeiro círculo do consumo" e de "demandar tolerância e impunidade dos privilegiados para os descaminhos de seu grupo e de seus aliados no poder". Assim, a posição discursiva de que provêm os enunciados de Ab'Sáber não corresponde nem àquela da grande mídia tradicional, que de maneira ora mais ora menos direta opõe-se ao governo liderado pelo PT, nem se confunde com a dos partidários desse governo, que tendem a apenas lhe render loas.

\section{A VOZ DE LULA E AS CONTRADIÇÕES DA HISTÓRIA DO BRASIL}

Após o anúncio do câncer de laringe de Lula e a notícia do restabelecimento de sua saúde, muitas vezes foram repetidas as "mesmas" afirmações: "a perda da voz de Lula seria uma grande perda..." e "uma das forças de Lula é a voz", tal como figuram manifesta e respectivamente nos textos de Ab'Sáber e Eliane Cantanhêde acima referidos. Os sentidos dessa privação e dessa potência definitivamente não são transparentes, evidentes e essenciais, mas construídos à medida que as palavras e os enunciados se inscrevem num ou noutro discurso. Quem perde e o que se perde com a perda da voz de Lula não são equivalentes para as duas posições acima identificadas. Do mesmo modo, a força dessa voz corresponde à aptidão comunicativa, à voracidade política, à verborragia demagógica, ao cálculo do poder e à manipulação popular, de um lado - ou seja, no discurso do qual emergem os dizeres da Folha e da Época -, e à capacidade de fazer ouvir a voz do povo oprimido, enfrentando poderosas elites, e/mas também a de ecoar as vozes conservadores de segmentos da sociedade brasileira, cuja fala consiste em "cimento ideológico condescendente consigo mesmo", que orienta o povo em massa para o mercado do consumo. Em mais de um sentido, as vozes dos sujeitos de uma sociedade não possuem a mesma consistência, a mesma força, o mesmo alcance e a mesma duração. 
A entrada e a saída de Lula de sua condição de presidente da República ligam-se tal como as faces de Janus e formam um único círculo virtuoso: sua vitória nas eleições presidenciais em 2002 foi considerada por membros de diversos segmentos sociais como um dos mais importantes acontecimentos da história brasileira e o final de sua gestão culminou com uma imensa aprovação popular em 2010. Ao longo desses oito anos, o ex-sindicalista conquistou um sucesso político praticamente hegemônico. Se não antes, já durante sua campanha eleitoral, prenunciava-se sua estratégia política e retórica para consegui-lo: "Eu vou conversar com todas as pessoas, vou tentar juntar todos os homens e todas as mulheres de bem do nosso querido Brasil!". Para falar a "todos" os brasileiros foram e continuam sendo precisos ao menos dois timbres...

A que se deve esse inegável êxito de Lula? À inédita, efetiva e eficaz implementação de programas sociais e à certa adesão não menos a aspectos da política arcaica, conservadora e clientelista da cultura brasileira, simultaneamente possíveis graças ao seu espírito conciliador e ao seu carisma popular. Em suas palavras e ações, o ex-presidente falou e fez como nunca antes algo pelos miseráveis e quase não falou e fez menos do que devia para alterar a absurda concentração de renda no país. A pedra angular de seu modus operandi foi a constante e explícita vontade de articular os polos extremos em seu governo, em seu corpo e em sua voz. Neles, Lula conciliou os ecos de sua condição de nordestino, trabalhador, pobre e popular, porque atento às mazelas de uma imensa parte de seu povo, e seu estado de brasileiro, presidente, burguês e cosmopolita, porque bem ajustado à lógica do capital globalizado.

Eis aí uma mistura bem brasileira entre um il faut faire e um laissez-faire, que redunda em insuficientes transformações eivadas de péssima conservação para os miseráveis e de ótima manutenção para os riquíssimos. Enfim, sua autoridade carismática foi produzida por reconhecimento e produziu obediência, mas não por um "poder extraordinário"; antes, Lula sempre se nos apresentou como um "igual": de maneira espontânea e emotiva, em léxico e gramática de meio-de-semana, ele pôde falar de pobreza, fome, analfabetismo e exploração com o lastro da autenticidade da experiência vivida. $\mathrm{O}$ carisma popular facilitou-lhe o estabelecimento de pactos mais ou menos conservadores com o pior das elites econômicas e políticas do Brasil.

No corpo e na voz de Lula está inscrita nossa história. Em sua mão esquerda, a ausência do dedo mínimo é a presença do poder da navalha na carne do trabalhador brasileiro, estigma de classe gravado em sua anatomia; porém, já há algum tempo que seu corpo não mais padece dos sofrimentos do trabalho duro. Por sua vez, a voz de Lula é também uma síntese de traços de diferentes temporalidades e valores da história brasileira: mediante suas propriedades e modulações, foram ouvidos gritos de dor, de resistência e de libertação, tal como num verso de Gregório de Matos: "O voz zelosa, que dobrada... brada"; mas também nela ecoaram antigas e renitentes vozes retrógradas.

A política não se encerra na fala, mas começa por ela. Em todas as sociedades, o exercício do poder passa pela fala e a fala, pela voz. Trata-se de um fenômeno político por excelência, porque suas marcas e inflexões consistem num elemento constitutivo e privilegiado do laço social. A voz de Lula - cujos traços de frequência lenta e tom 
grave, de qualidade rouca e áspera e de pronúncia por vezes abafada são conhecidos e reconhecidos por qualquer brasileiro - é em diferentes sentidos uma sua força e um elemento político por definição. Por essa razão, foi dito por ele e por outros que sua perda representaria "a morte de um tempo antes de seu próprio fim".

Ora, podemos constatar que há identidades e diferenças no que já se disse sobre a voz em épocas e lugares distintos. Por um lado, existem fortes ressonâncias e marcantes consonâncias entre o que retores e biólogos de tempos distintos disseram sobre ela. Por outro, Montaigne e Lula, afastados pelo tempo, pelo espaço e por diferenças de atitude, definitivamente não dizem a mesma coisa, quando de suas falas sobre a possibilidade de perdê-las: para o primeiro, a arte da conversação não corresponde a ouvir e a dizer o que cada um deseja escutar, ou seja, a eliminar as tensões; ao contrário, pretende promovêlas num firme, mas não violento e teimoso corpo a corpo. Para Lula, a perda da voz representa, antes, a ruína de sua comunicação carismática, conciliadora e dirigida aos muito ricos e aos muito pobres da nação brasileira. Com Lula, parte destes últimos conseguiu alguma vez e alguma voz, em sua inserção ao mercado básico de consumo e na possibilidade de projetar outros desejos nessa mesma ordem da mercadoria. Muito deles, contudo e infelizmente, continuam a esperar de longe pelo exercício efetiva de uma plena cidadania.

\section{REFERÊNCIAS}

AB’SABER, T. A voz de Lula. Serrote, São Paulo, IMS, n. 10, 2012, p. 63-71.

GOBBI, F. O que dizem por aí sobre a voz. 2004. 159 f. Dissertação (Mestrado em Fonoaudiologia) Pontifícia Universidade Católica de São Paulo, São Paulo, 2004.

HAROCHE, C.; HENRY, P.; PÊCHEUX, M. La sémantique et la coupure saussurienne: langue, langage, discours. Langages, Paris, n. 24, p. 93-106, 1971.

KARPF, A. La voix: un univers invisible. Paris, Autrement, 2008.

MONTAIGNE, M. Ensaios. Brasília: Editora da UNB; São Paulo: Hucitec, 1987.

ORLANDI, E. Interpretação: autoria, leitura e efeitos do trabalho simbólico. Rio de Janeiro: Vozes, 1998.

PARRET, H. La voix et son temps. Bruxelles: De Boeck Université, 2002.

PÊCHEUX, M. Análise automática do discurso. In: GADET, F.; HAK, T. (Orgs.). Por uma Análise automática do discurso: uma introdução à obra de Michel Pêcheux. Campinas: Editora da Unicamp, 1997a, p. 61-161.

PÊCHEUX, M. Semântica e discurso: uma crítica à afirmação do óbvio. Campinas: Editora da Unicamp, $1997 b$.

PIOVEZANI, C. Usos e sentidos da voz no discurso político eleitoral brasileiro. Alfa, São Paulo, v. 55, n. 1, p. 163-176, 2011.

SALAZAR. P-J. Darwin à Padoue: anthropologie de la voix au XVIIè et au XIXè siècles. In: CASSIN, B.; COHEN-LEVINAS, D. (Dir.). Vocabulaires de la voix. Paris: L'Harmattan, 2008, p. 37-51.

SINGER, A. Os sentidos do lulismo: reforma gradual e pacto conservador. São Paulo: Companhia das Letras, 2012. 35 . 
Recebido em: 18/05/14. Aprovado em: 03/02/15

Title: Speeches about Lula's voice in Brazilian media

Author: Carlos Piovezani

Abstract: Since the announcement of Lula's throat cancer on October 2011, the risks presented to the voice of the former president of Brazil gave rise to a wide range of comments. Based on Discourse Analysis, derived from Michel Pêcheux, in this essay we propose to analyze them in terms of their different positions and their distinct meanings. We further undertake a reflection on certain aspects of Brazilian history, which are preserved in one of the strongest voices of the country, in order to answer the following questions: Why was Lula's voice mentioned a number of times? What are the positions and implications of these comments? What role did his voice play in his public speeches, in the composition of his charisma, and in his political success?

Keywords: Discourse. Voice. Media.

Título: Discursos sobre la voz de Lula en los medios brasileños

Autor: Carlos Piovezani

Resumen: Desde el anuncio del cáncer de laringe de Lula en octubre 2011, vemos surgir un amplio y disperso conjunto de textos sobre los riesgos que la dolencia representaba para la voz del ex-presidente de Brasil. Fundamentados en el Análisis del Discurso, derivada de Michel Pêcheux, nuestra propuesta consiste en interpretar algunos de los enunciados de los medios brasileños que trataran de la voz de Lula, en la tentativa de identificar las distintas posiciones de sus enunciadores y sus diferentes sentidos. Buscamos, todavía, emprender una reflexión sobre ciertos aspectos de la memoria y de la historia brasileña, conservados en la voz de uno de sus personajes más importantes, no intuito de aventar posibles respuestas para las siguientes cuestiones: ¿por qué se he hablado tanto de su voz? ¿Cuáles son las posiciones y los sentidos de esas hablas sobre la voz de Lula? ¿Cuál es el role que ella jugó en su habla pública, en la composición de su carisma e en su suceso político?

Palabras-clave: Discurso. Voz. Medios de comunicación. 